\title{
Analysis of Best Practices to Prevent and Manage the Waste Generated in Building Rehabilitation Works
}

\author{
Paola Villoria Sáez ${ }^{1, * \mathbb{C}}$, Mercedes Del Río Merino ${ }^{1}$, César Porras-Amores ${ }^{1} \mathbb{D}$, \\ Jaime Santa Cruz Astorqui ${ }^{2}$ and Natalia González Pericot ${ }^{3}(\mathbb{D}$ \\ 1 TEMA Research Group, Departamento de Construcciones Arquitectónicas y su Control, Escuela Técnica \\ Superior de Edificación, Universidad Politécnica de Madrid, Avenida Juan de herrera, 6, 28040 Madrid, \\ Spain; mercedes.delrio@upm.es (M.D.R.M.); c.porras@upm.es (C.P.-A.) \\ 2 TEMA Research Group, Departamento de Tecnología de Edificación, Escuela Técnica Superior de \\ Edificación, Universidad Politécnica de Madrid, Avenida Juan de herrera, 6, 28040 Madrid, Spain; \\ jaime.santacruz@upm.es \\ 3 Departamento de Arquitectura, Diseño y Construcciones Civiles, Escuela de Arquitectura, Ingeniería y \\ Diseño, Universidad Europea de Madrid, 28670 Villaviciosa de Odón, Madrid, Spain; \\ natalia.gonzalez@universidadeuropea.es \\ * Correspondence: paola.villoria@upm.es
}

Received: 23 April 2019; Accepted: 13 May 2019; Published: 16 May 2019

\begin{abstract}
This paper carries out a survey conducted among the construction agents in order to evaluate the effectiveness and viability of several best practice measures regarding construction and demolition waste (CDW) management in building rehabilitation works. This survey was developed considering that in rehabilitation works two well differentiated activities are carried out: those of the dismantling of the building (deconstruction activities) and those of the execution of the new construction (construction activities). Results of this survey show that among the highly rated best practices for the design phase "designing the building in order to help the recovery of the materials at the end of its use" can be highlighted, despite less than $25 \%$ of respondents usually implement this measure in their works. Moreover, according to BP during the construction phase, the results reveal that only $70 \%$ of respondents routinely implement the most valued measure "Hiring authorized companies for the management of CDW" and 60\% the second "Respecting the manufacturer's directions regarding the transport, collection and commissioning".
\end{abstract}

Keywords: Construction waste; waste management under construction; best practices; assessment; rehabilitation works; construction survey

\section{Introduction}

Currently, the construction/deconstruction sectors are responsible of generating the largest volume of waste, which is defined as construction and demolition waste (CDW), and usually includes a mixture of inert waste (90\%), non-hazardous waste (9\%), and hazardous waste (1\%) [1]. For instance, China approximately generated 1.13 billion tons of CDW in 2014, while the United States and Europe generated around 548 Mtonnes and 923.9 Mtonnes respectively [2-5]. The severity of the CDW generation not only depends on the amount generated, but also on its management. In general, the quantity, composition, and recycling rate of CDW vary between regions and depend on other region-specific factors influencing its generation [6]. For instance, the European Union has a recycling rate ranging between 40-99\%. Considering this situation, the European Parliament approved the Waste Framework Directive 2008/98/EC (WFD) [7] in order to promote prevention and CDW recycling. The WFD establishes general measures to promote waste prevention and recovery as well as sets a specific target for CDW recovery which needs to be met by 2020 (recycling rate above 70\%). 
Therefore, it is essential to implement best environmental practice measures to prevent waste from landfill or reduce the amount of waste that cannot be avoidable $[8,9]$. In this sense, BPs seek to ensure that the activities carried out within the building project have the lowest possible environmental impact, and for this reason, they improve the social image of the company towards its clients. In this sense, different guides of good environmental practices in building constructions have been developed in terms of CDW management and other environmental impacts. In general, the guides are organized according to the different phases to be developed in the building process, i.e.: design phase, construction, use, and conservation, and finally deconstruction phase. These BPs consider not only the rationalization in the use of natural resources, but also the reduction of the volume of generated waste and the improvement of its management.

In general, when you want to reduce the impacts that the activities of companies have on the environment, the first thing that generally arises is replacing the materials, modifying the units, and design of new products $[10,11]$. However, the possibility of reducing negative environmental impact is not always reflected through changes in the organization of processes and activities; i.e., through BP [12].

Some companies are aware of the impact the sector has on the natural environment, and how its degradation can affect the business itself. Specifically, in Spain, several construction companies are implementing best practices to reduce the amount of waste generated. The construction company Fomento de Construcciones y Contratas (FCC Construcción) indicated in the annual report that during the past year several best practices to minimize the waste generated were implemented [13]. Moreover, another Spanish construction company, Arpada, returns directly to the factory the waste generated from laminated plasterboards. This waste is then added to the manufacturing process of laminated plasterboards and thus the generation of CDW in the execution of the construction work is reduced [14]. The Sustainability report of Acciona focused on the environmental training of its workers as a preventive tool to ensure the participation and commitment of the employees [15]. In addition, it incorporates to its activity several processes oriented to the minimization of the waste and the selection of ecofriendly materials more respectful with the natural environment. However, these examples are in contradiction with the conclusions reached in previous studies where it was established that the great majority of construction companies do not implement or use BP regularly [16,17]. In this sense, the commitment of the management is crucial and motivates the participation of the employees for a better management of the resources and respect of the environment, with the consequent reduction of impacts and their associated costs.

\section{Literature Review on Construction and Demolition Waste Best Practices}

Despite the construction waste is generated during the execution phase, a third of the total CDW generated in a construction work is a direct consequence of the decisions made during the design phase $[18,19]$. Therefore, several studies identify and analyze the effectiveness of BP for CDW management, both in the design and in the execution phase. Among the best practices in the design phase the following best practices can be highlighted:

- Providing a space in the work for the correct collection of generated CDW, which allows to guarantee the characteristics of the CDW until the moment of its use, avoiding their contamination by hazardous waste $[20,21]$.

- Detecting those construction units that can support reusable materials from the construction site itself. [22]

- Using prefabricated systems that hardly generate waste and avoid the generation of waste by cutting and transforming elements on site. [23,24]

- Designing the building based on the dry assembly of materials to facilitate the deconstruction and segregation at the end of their useful life (design for deconstruction) $[22,25,26]$.

- Using materials with a high content of recycled material $[27,28]$ 
As for best practices in the execution phase, numerous studies have been performed, from out of which the following BPs can be highlighted:

- Planning the number of containers and size required in each activity [16,29]. For this, the use of tools to estimate the amount of waste that will be generated during the construction-such as Arquímedes database in Spain or Net waste tools in the United Kingdom-are recommended.

- Recording the quantities and characteristics of the waste that leaves the work to obtain data of own CDW generation, according to their own way of working [30,31].

- Performing periodic controls on the use of CDW containers to avoid that different categories of CDW are placed in the wrong container [29].

- Following the plans of the project so as not to make any more unexpected works and thus produce more CDW [32].

- Performing on-site segregation of each waste category. The segregation of waste results in higher purity waste, with greater possibility for its recovery [22].

- Following the manufacturer's instructions in the collection of material. Bad practices in the handling of materials in the works are causing a loss of approximately $15 \%$ of the raw materials, increasing the amount of construction waste to be managed [18].

- Organizing talks and training for the operators in the matter of waste management to achieve a correct management of the waste on site [16].

- Distributing small containers in the working areas to facilitate the segregation of the different types of waste [16].

- $\quad$ Reducing the excess of material requested to avoid material tearing on site $[18,33]$.

- Buying materials that avoid unnecessary wrapping [34].

- Planning CDW coordination and review meetings to ensure that measures are being taken for proper management of CDW [22].

- Using crushers or on-site compactors for CDW [21,22].

As for studies analyzing the effectiveness of BPs to promote recovery and recycling versus final disposal, Tam [35] investigated the effectiveness of the implementation of the CDW management plan in each construction site. The results showed that the proposed methods for in situ minimization, reuse, and waste separation are the main benefits obtained following the implementation of the Waste Management Plan. Similarly, studies by Lu and Yuan [32] and Wang et al. [21] identified several factors that influence on the CDW management system in China. Villoria et al. [16] analyzed the effectiveness and viability of the most recurrent BPs in the execution of new buildings.

In short, several studies have been found that identify BP in the design and execution phases, but none of them-except the work of Villoria et al. [16] which focused on new constructions-assess the implementation of BP from the point of view of the type of work: new building construction or rehabilitation/demolition work.

In fact, assessing the effectiveness and viability of BP in building rehabilitation works is essential as the European forecasts indicate an increase of buildings' rehabilitation works and consequently an increase of CDW generation [36]. In particular, in Spain, due to the new energy efficiency regulations, it is necessary to refurbish around 400,000 homes a year in order to achieve the energy target set by 2050 [31].

Therefore, knowing that the intervention in existing buildings should not be left out of the waste management and must meet the same requirements that are made for new construction, an in depth analysis of BP for deconstruction/rehabilitation works is conducted.

\section{Materials and Methods}

For the development of the work, the methodology described in several previous works was followed, consisting on three phases [16,21,32] (See Figure 1). 


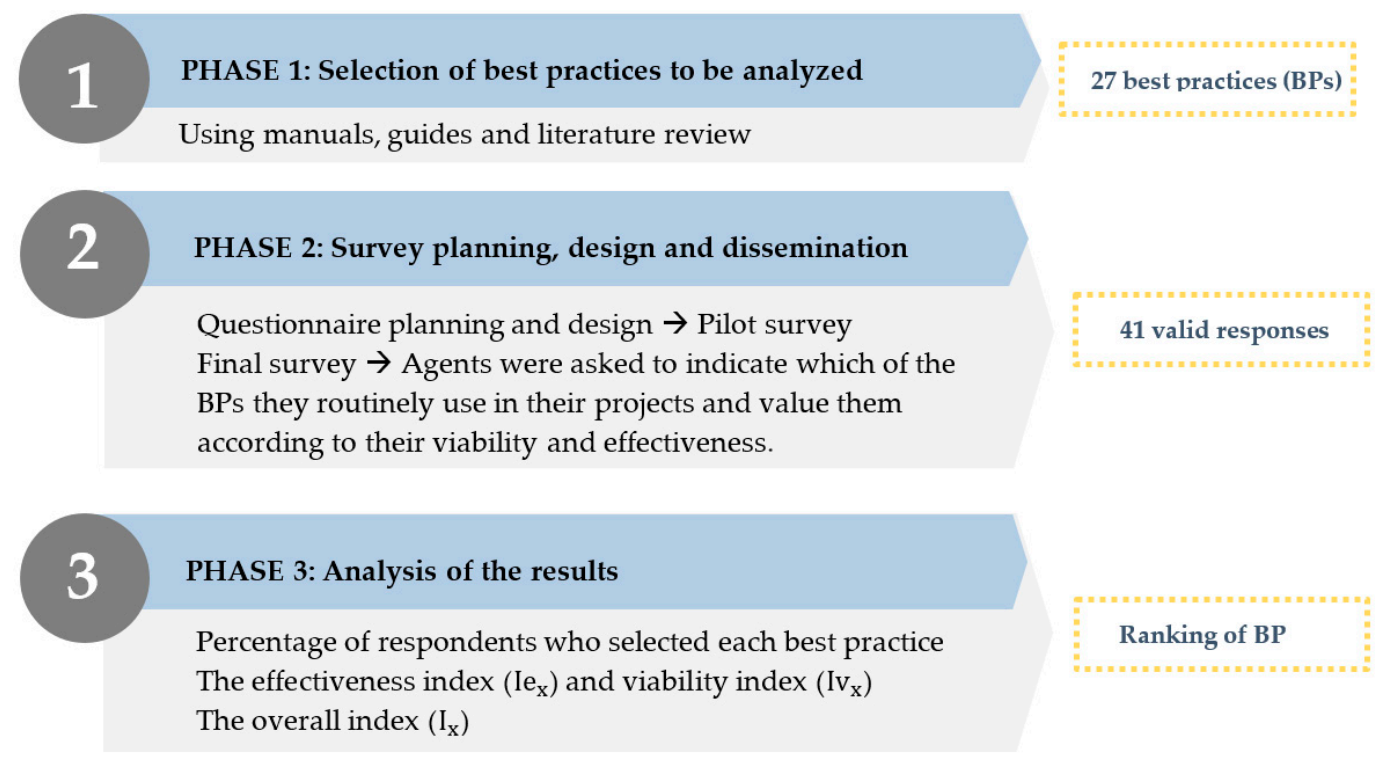

Figure 1. Scheme of the methodology followed.

Phase 1: a search on best practices was carried out in the different Guides and Manuals of CDW management, searching for specific BP for rehabilitation works [21-30]. Among these Manuals, only five incorporate a specific section of best practices in rehabilitation or deconstruction work, namely rehabilitation using selective deconstruction techniques, such as:

- $\quad$ Planning selective demolition techniques

- Removing not fixed debris and decorative elements.

- Neatly dismantling carpentry, sanitary equipment

- Uninstalling heating networks, plumbing, electricity, etc.

- Dismantling exterior elements, false ceilings, and recoverable coatings.

- Dismantling roofs, covers and interior divisions.

- Demolishing the structure in a controlled manner.

From the list of all best practices identified in the Guides and Manuals [21-30], a selection has been made considering the number of times the best practice appears in the consulted bibliography (greater than or equal to five). To the list of the selected BPs, other BPs identified in the previous research works-discussed in the literature review (Section 2) - , were added in order to avoid leaving a BP out of the assessment. Merging the BPs found in the Guides and Manuals and the ones identified in the literature review, a list of BPs was stablished to be further studied. Table 1 classifies the selected BPs according to the phase in which they would be implemented (design or execution phase) and establishes if the best practice is directed towards the prevention and minimization of the waste (P/MI), its correct management (CM) or both. 
Table 1. List of best practices to be analyzed.

\begin{tabular}{|c|c|c|c|c|c|}
\hline & Code & Best Practices & $\begin{array}{l}\text { Refurbish/ } \\
\text { Deconstruction } \\
\text { Activities }\end{array}$ & $\begin{array}{l}\text { Construction } \\
\text { Activities }\end{array}$ & Type \\
\hline \multirow{5}{*}{ 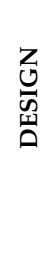 } & D. $1^{*}$ & $\begin{array}{l}\text { Use materials with a high content of recycled material, natural } \\
\text { materials and/or eco-labeled }\end{array}$ & $\checkmark$ & $\checkmark$ & $\mathrm{CM}$ \\
\hline & D. $2 *$ & $\begin{array}{l}\text { Design the building to facilitate the recovery of the elements at the } \\
\text { end of their useful life. }\end{array}$ & $\checkmark$ & $\checkmark$ & $\mathrm{P} / \mathrm{MI} / \mathrm{CM}$ \\
\hline & D. $3 *$ & $\begin{array}{l}\text { Use construction techniques which generate less waste (prefabricated } \\
\text { or industrialized elements). }\end{array}$ & $\checkmark$ & $\checkmark$ & $\mathrm{P} / \mathrm{MI}$ \\
\hline & D.4 D & Planning selective demolition techniques & $\checkmark$ & - & $\mathrm{CM}$ \\
\hline & D. $5 *$ & Provide space for collecting and storing CDW & $\checkmark$ & $\checkmark$ & $\mathrm{CM}$ \\
\hline \multirow{22}{*}{ 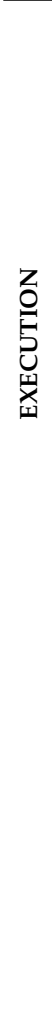 } & C.1 D & Remove decorative elements. & $\checkmark$ & - & $\mathrm{CM}$ \\
\hline & C.2 D & Neatly dismantle carpentry, sanitary equipment & $\checkmark$ & - & $\mathrm{CM}$ \\
\hline & C.3 D & Uninstall heating networks, plumbing, electricity, etc. & $\checkmark$ & - & $\mathrm{CM}$ \\
\hline & C.4 D & Dismantle exterior elements, false ceilings and recoverable coatings. & $\checkmark$ & - & $\mathrm{CM}$ \\
\hline & C.5 D & Dismantle roofs, covers and interior divisions. & $\checkmark$ & - & $\mathrm{CM}$ \\
\hline & C.6 D & Demolish the structure in a controlled manner. & $\checkmark$ & - & $\mathrm{CM}$ \\
\hline & C. $7^{*}$ & $\begin{array}{l}\text { Estimate the mass and volume of waste to be generated, as well as the } \\
\text { type and quantity of containers required. }\end{array}$ & $\checkmark$ & $\checkmark$ & $\mathrm{CM}$ \\
\hline & C. $8^{*}$ & Hire authorized companies for the management of waste. & $\checkmark$ & $\checkmark$ & $\mathrm{CM}$ \\
\hline & C. $9 *$ & Purchase bulk materials to reduce packaging waste & $\checkmark$ & $\checkmark$ & $\mathrm{P} / \mathrm{MI}$ \\
\hline & C. $10 *$ & $\begin{array}{l}\text { Hire suppliers who manage the waste of their products and/or have } \\
\text { an environmental certificate. }\end{array}$ & $\checkmark$ & $\checkmark$ & $\mathrm{CM}$ \\
\hline & C. $11 *$ & $\begin{array}{l}\text { Maximum use of materials and products, using mixing systems with } \\
\text { mechanical dosing. }\end{array}$ & $\checkmark$ & $\checkmark$ & $\mathrm{P} / \mathrm{MI}$ \\
\hline & C. $12 *$ & $\begin{array}{l}\text { Manage the reception and collection of the products according to the } \\
\text { needs of use in each moment to avoid the generation of waste of } \\
\text { damaged/expired material. }\end{array}$ & $\checkmark$ & $\checkmark$ & $\mathrm{P} / \mathrm{MI}$ \\
\hline & C.13* & $\begin{array}{l}\text { Follow the manufacturer's instructions regarding the transportation, } \\
\text { collection and storing of materials to avoid breakage. }\end{array}$ & $\checkmark$ & $\checkmark$ & $\mathrm{P} / \mathrm{MI}$ \\
\hline & C.14* & Establish a container for each type of CDW and respect its use. & $\checkmark$ & $\checkmark$ & $\mathrm{CM}$ \\
\hline & C.15* & Use small containers in the working areas. & $\checkmark$ & $\checkmark$ & $\mathrm{CM}$ \\
\hline & C. $16^{*}$ & $\begin{array}{l}\text { Reuse materials within the construction site. Detect those activities } \\
\text { that can support reusable materials from the site itself. }\end{array}$ & $\checkmark$ & $\checkmark$ & $\mathrm{CM}$ \\
\hline & C. $17^{*}$ & $\begin{array}{l}\text { Training and informing all workers about the correct labelling of } \\
\text { containers and their responsibilities in the field of waste management. }\end{array}$ & $\checkmark$ & $\checkmark$ & $\mathrm{P} / \mathrm{MI} / \mathrm{CM}$ \\
\hline & C. $18^{*}$ & $\begin{array}{l}\text { Use of onsite machinery for CDW management (crushers and } \\
\text { compactors). }\end{array}$ & $\checkmark$ & $\checkmark$ & $\mathrm{CM}$ \\
\hline & C. $19^{*}$ & $\begin{array}{l}\text { Record the date of generation, quantities and characteristics of the } \\
\text { waste. }\end{array}$ & $\checkmark$ & $\checkmark$ & $\mathrm{CM}$ \\
\hline & C. $20^{*}$ & $\begin{array}{l}\text { Create documents that collect instructions regarding the different } \\
\text { activities generating waste to ensure that each task is well defined. }\end{array}$ & $\checkmark$ & $\checkmark$ & $\mathrm{P} / \mathrm{MI} / \mathrm{CM}$ \\
\hline & C. $21 *$ & CDW control and follow up. & $\checkmark$ & $\checkmark$ & $\mathrm{CM}$ \\
\hline & C. $22 *$ & Commitment to apply BP as a complementary criterion for hiring & $\checkmark$ & $\checkmark$ & $\mathrm{P} / \mathrm{MI} / \mathrm{CM}$ \\
\hline
\end{tabular}

Phase 2: in order to evaluate the effectiveness and viability of the selected best practices and to know which of them are currently implemented, a survey has been carried out on the best practices that they routinely implement and their opinion on their effectiveness and viability (see Supplementary Materials). A preliminary questionnaire was prepared and after a revision and approval of a board of experts, the definitive survey was disseminated. The survey was developed considering that in a rehabilitation work two well differentiated activities are carried out: those related to dismantling and reform of the building (deconstruction) and those related to the execution of the new construction (construction). For this reason, the survey was structured into three sections according to the following scheme:

1. General data of the respondents

2. Best practices in the design phase of rehabilitation works

- Deconstruction activities

- Construction activities

3. Best practices in the execution phase of rehabilitation works 
- Deconstruction activities

- Construction activities

In Sections 2 and 3, the agents were asked to (1) indicate which of the BP they routinely use in their projects and (2) to value each BP according to its viability and effectiveness on a Likert scale of 1 to 5 , where 5 denotes a very effective or viable measure and 1 means insignificant or not viable. In both sections, respondents were allowed to write other measures that were not included in the list offered. This allowed identifying other best practices that were not included in the questionnaire.

The survey was sent to a total of 84 construction agents in Madrid, who were randomly selected from construction companies with a number of employees ranging from 20 to 99 . A total of 41 valid responses were received.

Phase 3: regarding the data analysis, results obtained for the best practices, the percentage of the total of the respondents who selected a best practice was calculated.

To assess the viability and effectiveness of each BP, respondents' ratings on each of the best practices were statistically analyzed using Statgraphics Centurion XVI.II. In short, the analysis calculates coefficients as the median $(\mathrm{Me})$, the standard deviation $(\sigma)$ and the mean effectiveness index $\left(\mathrm{Ie}_{\mathrm{x}}\right)$ and viability index $\left(\mathrm{Iv}_{\mathrm{x}}\right)$, which are calculated with Equation (1). This equation has been widely used to identify the effectiveness of various factors and variables $[16,21,32]$.

$$
I_{x}=\frac{\sum_{y=1}^{5} N_{x y} V_{y}}{\sum_{y=1}^{5} N_{x y}} \quad(\mathrm{x}=1,2, \ldots 27 ; \mathrm{y}=1,2,3,4,5)
$$

Being:

- $\quad \mathrm{IX}_{\mathrm{X}}$ Is the index of the BP analyzed (x). Viability index $\left(\mathrm{Iv}_{\mathrm{x}}\right)$ or effectiveness index $\left(\mathrm{Ie}_{\mathrm{x}}\right)$

- $\quad V_{Y}$ Is the average valuation of the agents surveyed for the BP analyzed $\left(\mathrm{y}_{1}=1, \ldots, \mathrm{y}_{5}=5\right)$.

- $\quad \mathrm{N}_{\mathrm{X}}$ is the number of agents that chose a valuation (y) for the analyzed BP (x).

In addition to obtaining the characteristic statistical values, the final valuation of each selected BPs was calculated as the mean value of the viability index $\left(\mathrm{Iv}_{\mathrm{x}}\right)$ and the effectiveness index $\left(\mathrm{Ie}_{\mathrm{x}}\right)$. Finally, best practices were classified according to the score obtained by the final valuation. If two BPs had the same score, they were classified according to their medians and, in case of coinciding indexes and medians; they were classified according to their typical deviations.

Finally, the results obtained in this study (BPs in rehabilitation works) were compared, with the conclusions of other works focused on BPs in new construction works.

\section{Results and Discussion}

The composition of the survey respondents were agents from building construction (100\%), out of which $29 \%$ were experts in rehabilitation/deconstruction projects. The remaining percentage, $71 \%$, had expertise in both new building construction and rehabilitation/deconstruction projects. The majority of respondents were qualified technicians (93\%), including environmental coordinators and project managers, followed by company managers $(7 \%)$. All respondents had an expertise between 1 and 3 years $(7 \%)$ and over 5 years (93\%). In addition, respondents were invited to assess their training and experience regarding CDW management on a 5-point scale, where 5 denoted very high and 1 very poor. Results show an average value of 4.82 , which is medium-high knowledge.

\subsection{Results of the Most Implemented Best Practices}

It is observed that all the best practices established by the researchers correspond to some of the BP determined in the Guides, with one exception: "Optimizing resistant sections to reduce the amount of material to be used". On the other hand, some of the most repeated best practices in the Guides were not considered by the researchers, such as: 
- Writing documents that collect instructions regarding the different processes that generate waste and emissions.

- $\quad$ Reusing materials within the work. Detecting those items that can support reusable materials from the work itself.

- Maximum use of materials and products, using mixing systems with mechanical dosing.

- Hiring authorized companies for the management of waste.

- Commitment to apply Best Practices as a complementary criterion for the award of the work.

\subsubsection{Best Practices in the Design Phase of Rehabilitation Works}

During the Planning of Deconstruction Activities of the Building

The results of the survey show that the most common best practice when designing the deconstruction and dismantling activities of a rehabilitation building is "Providing a space for the collection of CDW" (Table 2).

Table 2. Percentage of respondents who routinely implement this BP during the design of the building dismantling activities in a rehabilitation.

\begin{tabular}{clc}
\hline \multicolumn{1}{c}{ Best Practices } & \% Response \\
\hline D.4 D & Planning selective demolition techniques & $61.54 \%$ \\
D.5 * & Providing a space for the collection of CDW. & $69.23 \%$ \\
& None & $7.14 \%$
\end{tabular}

*: BP applicable to deconstruction and construction activities. D: BP exclusive of deconstruction activities. a Respondents can select more than one response, so the percentages exceed $100 \%$.

During the Planning of Construction Activities Carried out in a Rehabilitation

Regarding the results of the most common best practices in the design phase of the construction activities carried out in a rehabilitation project, it can be observed that the construction techniques that hardly generate waste is the most implemented best practice by the agents surveyed (Table 3).

Table 3. Percentage of respondents who routinely implement this BP during the design of activities related to a new construction in a rehabilitation project.

\begin{tabular}{|c|c|c|}
\hline \multicolumn{2}{|r|}{ Best Practices } & \multirow{2}{*}{$\begin{array}{c}\text { \% Response }^{\mathrm{a}} \\
24.00 \%\end{array}$} \\
\hline D. 1 * & $\begin{array}{l}\text { Use materials with a high content of recycled } \\
\text { material, natural materials and/or eco-label. }\end{array}$ & \\
\hline D. 3 * & $\begin{array}{l}\text { Use construction techniques that generate less } \\
\text { waste (prefabricated or industrialized elements). }\end{array}$ & $48.00 \%$ \\
\hline D. $2 *$ & $\begin{array}{l}\text { Design the building to facilitate the recovery of the } \\
\text { elements at the end of their useful life. }\end{array}$ & $12.00 \%$ \\
\hline \multirow[t]{2}{*}{ D. $5^{*}$} & Providing a space for the collection of CDW. & $76.00 \%$ \\
\hline & None & $10.71 \%$ \\
\hline
\end{tabular}

${ }^{*}$ BP applicable to deconstruction and construction activities. ${ }^{a}$ Respondents can select more than one response, so the percentages exceed $100 \%$.

In this case, the agents which usually do not implement any best practice surpass $10 \%$ of the respondents.

\subsubsection{Best practices in execution phase of Rehabilitation Works}

During the Execution of Deconstruction Activities and Dismantling of the Building

The results show that all respondents implement best practices in their works. The most common $\mathrm{BP}$ when carrying out the dismantling of the building are "Contracting authorized companies for 
waste management" followed by all best practices exclusive to selective demolition activities (C1-C6) (Table 4).

Table 4. Percentage of respondents who routinely implement this BP during the execution of the deconstruction activities of the building in a rehabilitation.

\begin{tabular}{|c|c|c|}
\hline & Best Practices in Execution Phase & $\%$ Response $^{a}$ \\
\hline C.1 D & Removing decorative elements. & $71.43 \%$ \\
\hline C.2 D & Dismantling neatly carpentry, sanitary equipment & $82.14 \%$ \\
\hline C.3 D & Uninstalling heating networks, plumbing, electricity, etc. & $78.57 \%$ \\
\hline C. $4 \mathrm{D}$ & Dismantling exterior elements, false ceilings and recoverable coatings. & $71.43 \%$ \\
\hline C.5 D & Dismantling roofs, covers and interior divisions. & $67.86 \%$ \\
\hline C.6 D & Demolishing the structure in a controlled manner. & $67.86 \%$ \\
\hline $\mathrm{C} .7^{*}$ & $\begin{array}{l}\text { Estimating the mass and volume of waste to be generated, as well as the type and } \\
\text { quantity of containers required. }\end{array}$ & $57.14 \%$ \\
\hline C. $8^{*}$ & Hiring authorized companies for the management of waste. & $85.71 \%$ \\
\hline C. $14 *$ & Establishing a container for each type of CDW and respect its use. & $53.57 \%$ \\
\hline C. $15^{*}$ & Using small containers in work areas. & $25.00 \%$ \\
\hline C. $17^{*}$ & $\begin{array}{l}\text { Training and informing all personnel of the correct labeling of containers and } \\
\text { their responsibilities in the field of waste. }\end{array}$ & $32.14 \%$ \\
\hline C. $18^{*}$ & Use of machinery for the management of CDW (crushers and compactors). & $7.14 \%$ \\
\hline C. $19 *$ & Recording the date of withdrawal, quantities and characteristics of the waste. & $14.29 \%$ \\
\hline C. $20 *$ & $\begin{array}{l}\text { Creating documents that collect instructions regarding the different processes } \\
\text { that generate waste to ensure that each task is well defined. }\end{array}$ & $21.43 \%$ \\
\hline C. $21 *$ & Control and follow up. & $25.00 \%$ \\
\hline \multirow[t]{2}{*}{ C. $22 *$} & $\begin{array}{l}\text { Commitment to apply Best Practices as a complementary criterion for the award } \\
\text { of the work }\end{array}$ & $10.71 \%$ \\
\hline & None & $0.00 \%$ \\
\hline
\end{tabular}

*: BP applicable to deconstruction and construction activities. D: BP exclusive of deconstruction activities.

a Respondents can select more than one response, so percentages can exceed $100 \%$.

The use of on-site machines, such as crushers or compactors, is the least implemented best practice. This fact can be due to the lack of space that usually there is in this type of works. However, special jaws are currently commercialized, compatible with current demolition machines, which allow the waste to be crushed while the building is demolished. This can definitely avoid the use of an additional crushing machine and consequently the need to have a space at the site for its location.

During the Execution of Construction Activities Carried out in a Rehabilitation

The results from Table 5 show that the most implemented BP is "Hiring authorized companies for the management of waste". Although this BP is the most implemented, a higher percentage was expected since it is a BP enforced by the current legislation.

The next most implemented BP were "respecting the manufacturer's instructions regarding the transport, collection, and commissioning of materials", "estimating the generated CDW" and "establishing a container for each type of CDW". On the contrary, using mechanical dosing mixing systems is the least implemented best practice by the respondents. These results are similar to those obtained by Villoria et al. [16] for new construction of residential buildings, in which it was pointed out that the estimation of CDW is one of the most implemented BP and the use of crushing machines the least usual. 
Table 5. Percentage of respondents who routinely implement this BP during the execution of activities of new construction in a rehabilitation.

\begin{tabular}{|c|c|c|}
\hline \multicolumn{2}{|r|}{ Best Practices in Execution Phase } & $\%$ Response ${ }^{a}$ \\
\hline C. $7^{*}$ & $\begin{array}{l}\text { Estimating the mass and volume of waste to be generated, as well as the type and quantity } \\
\text { of containers required. }\end{array}$ & $53.57 \%$ \\
\hline C. $8^{*}$ & Hiring authorized companies for the management of waste. & $71.43 \%$ \\
\hline C. $9 *$ & Purchase of bulk materials to reduce packaging and generate less waste. & $14.29 \%$ \\
\hline C. $10 *$ & $\begin{array}{l}\text { Hiring suppliers who manage the waste of their products and/or having some type of } \\
\text { environmental certificate. }\end{array}$ & $35.71 \%$ \\
\hline C. $11 *$ & Maximum use of materials and products, using mixing systems with mechanical dosing. & $10.71 \%$ \\
\hline C. $12 *$ & $\begin{array}{l}\text { Managing the reception and collection on the work of the products according to the needs } \\
\text { of use in each moment to avoid the generation of waste of damaged/expired material. }\end{array}$ & $32.14 \%$ \\
\hline C.13* & $\begin{array}{l}\text { Observing the manufacturer's instructions regarding the transportation, collection, and } \\
\text { commissioning of materials to avoid breakage. }\end{array}$ & $60.71 \%$ \\
\hline C. $14 *$ & Establishing a container for each type of CDW and respect its use. & $53.57 \%$ \\
\hline C. $15^{*}$ & Using small containers in work areas. & $25.00 \%$ \\
\hline C. $16^{*}$ & $\begin{array}{l}\text { Reusing materials within the work. Detecting those items that can support reusable } \\
\text { materials from the work itself. }\end{array}$ & $39.29 \%$ \\
\hline C. $17 *$ & $\begin{array}{l}\text { Training and informing all personnel of the correct labeling of containers and their } \\
\text { responsibilities in the field of waste. }\end{array}$ & $28.57 \%$ \\
\hline C. $18 *$ & Use of machinery for the management of CDW (crushers and compactors). & $3.57 \%$ \\
\hline C. $19 *$ & Recording the date of withdrawal, quantities and characteristics of the waste. & $14.29 \%$ \\
\hline C. $20 *$ & $\begin{array}{l}\text { Creating documents that collect instructions regarding the different processes that } \\
\text { generate waste to ensure that each task is well defined. }\end{array}$ & $17.86 \%$ \\
\hline C. $21 *$ & Control and follow up. & $28.57 \%$ \\
\hline \multirow[t]{2}{*}{ C. $22 *$} & $\begin{array}{l}\text { Commitment to apply Best Practices as a complementary criterion for the award of } \\
\text { the work }\end{array}$ & $14.29 \%$ \\
\hline & None & $0.00 \%$ \\
\hline
\end{tabular}

*: BP applicable to deconstruction and construction activities. ${ }^{a}$ Respondents can select more than one response, so the percentages exceed $100 \%$.

\subsection{Evaluation of the Effectiveness and Feasibility of Best Practices for Rehabilitation Works}

The following is a descriptive analysis of the results obtained, which has been classified into two categories: Best practices in the design phase and best practices in the execution phase.

\subsubsection{Evaluation of Best Practices in Design Phase}

Table 6 shows the effectiveness and viability index. The median and standard deviation of the valuations obtained in the survey for each best practice under study in the design phase. From the results obtained, it can be observed that no measure obtained an index lower than 3.00 , both for the viability and effectiveness results, reason why all the measures can be considered medium-high.

Table 6. Classification of BP in the design phase for rehabilitation works according to the effectiveness and viability index.

\begin{tabular}{|c|c|c|c|c|c|c|c|c|c|}
\hline \multirow{3}{*}{ Ref. } & \multicolumn{9}{|c|}{$I_{X}$ Design Phase } \\
\hline & \multicolumn{3}{|c|}{ Effectiveness } & \multicolumn{3}{|c|}{ Viability } & \multicolumn{3}{|c|}{ Mean } \\
\hline & $\mathrm{Me}$ & $\mathbf{I e}_{\mathrm{x}}$ & $\sigma$ & $\mathrm{Me}$ & $I v_{x}$ & $\sigma$ & Ix & $\sigma$ & Ranking \\
\hline D. $5 *$ & 4.00 & 4.07 & 0.94 & 4.00 & 4.00 & 1.05 & 4.04 & 1.00 & $1^{\circ}$ \\
\hline D. 4 D & 4.00 & 4.04 & 0.92 & 4.00 & 3.79 & 0.99 & 3.91 & 0.96 & $2^{\circ}$ \\
\hline D. $2 *$ & 4.00 & 3.93 & 0.94 & 3.00 & 3.32 & 1.09 & 3.63 & 1.02 & $3^{\circ}$ \\
\hline D. $3 *$ & 4.00 & 3.50 & 1.20 & 3.00 & 3.21 & 1.26 & 3.36 & 1.23 & $4^{\mathrm{o}}$ \\
\hline D. $1^{*}$ & 4.00 & 3.69 & 1.22 & 3.00 & 3.00 & 1.19 & 3.32 & 1.21 & $5^{\circ}$ \\
\hline
\end{tabular}

*: BP applicable to deconstruction and construction activities. D: BP exclusive of deconstruction activities.

Likewise, the agents surveyed point out as more effective and also more viable measures ( $\mathrm{Ie}_{\mathrm{X}}$ and $\mathrm{Iv}_{\mathrm{X}}$ greater than 4.00) using construction techniques that hardly generate waste and providing a space on site for the collection of CDW. The practice considered as the least viable corresponds to the use of 
materials with recycled CDW content, which obtained a viability index equal to 3.00 . The rest of the measures were valued between 3.00 and 4.00 .

The results obtained highlight the following BP: The provision of space on site for the management of the CDW and the planning of selective demolition techniques with an IX around 4.00. This means that these measures tend to be high. In terms of the least effective and viable practices, the use of materials with a high content of recycled material, natural materials and/or eco-labeled, was selected by less than $25 \%$ of the respondents.

\subsubsection{Evaluation of Best Practices in Execution Phase}

Table 7 shows the effectiveness and viability index, the median and standard deviation of the rates obtained in the survey for each BP applicable only to deconstruction activities in the execution phase (C.1D - C.6D). Those BP applicable only to deconstruction activities have been highly rated according to both: viability and effectiveness. Dismantling the doors, windows, and sanitary equipment and removing decorative elements were the two BP rated as more viable. These best practices coincide with the most frequently used BP stated by the respondents in Table 4. In addition, "demolishing the structure in a controlled manner" is the BP less effective and viable, despite more than $60 \%$ of the respondents usually implements it in their works.

Table 7. Ranking of BPs in the execution phase according to the effectiveness and viability index.

\begin{tabular}{|c|c|c|c|c|c|c|c|c|c|c|}
\hline \multirow{3}{*}{ Ref. } & \multicolumn{10}{|c|}{ Ix } \\
\hline & \multicolumn{3}{|c|}{ Effectiveness } & \multicolumn{3}{|c|}{ Viability } & \multicolumn{3}{|c|}{ Mean } & \multirow{2}{*}{ Ranking } \\
\hline & $\mathrm{Me}$ & $\mathbf{I e}_{\mathrm{X}}$ & $\sigma$ & $\mathrm{Me}$ & $\mathbf{I} \mathbf{v}_{\mathbf{x}}$ & $\sigma$ & Me & Ix & $\Sigma$ & \\
\hline C.2 D & 4.00 & 4.15 & 1.04 & 5.00 & 4.21 & 0.97 & 4.50 & 4.18 & 1.01 & $1^{\circ}$ \\
\hline C.1 D & 4.00 & 3.96 & 0.93 & 4.00 & 4.08 & 0.95 & 4.00 & 4.02 & 0.94 & $2^{\circ}$ \\
\hline C.4 D & 4.00 & 3.95 & 1.02 & 3.00 & 3.91 & 1.02 & 3.50 & 3.93 & 1.02 & $3^{\circ}$ \\
\hline C. $5 \mathrm{D}$ & 4.00 & 3.89 & 1.18 & 3.00 & 3.95 & 1.20 & 3.50 & 3.92 & 1.19 & $4^{\circ}$ \\
\hline C.3 D & 4.00 & 4.00 & 1.14 & 4.00 & 3.80 & 1.18 & 4.00 & 3.90 & 1.16 & $5^{\circ}$ \\
\hline C.6 D & 4.00 & 3.88 & 1.02 & 2.00 & 3.01 & 1.12 & 3.00 & 3.45 & 1.07 & $6^{\circ}$ \\
\hline
\end{tabular}

Moreover, Table 8 shows the results obtained for each best practice for construction activities in the execution phase.

Table 8. Ranking of BPs in the execution phase according to the effectiveness and viability index.

\begin{tabular}{|c|c|c|c|c|c|c|c|c|c|c|}
\hline \multirow{3}{*}{ Ref. } & \multicolumn{10}{|c|}{ Ix } \\
\hline & \multicolumn{3}{|c|}{ Effectiveness } & \multicolumn{3}{|c|}{ Viability } & \multicolumn{3}{|c|}{ Mean } & \multirow{2}{*}{ Ranking } \\
\hline & Me & $\mathrm{Ie}_{\mathrm{X}}$ & $\sigma$ & Me & $I v_{x}$ & $\sigma$ & Me & Ix & $\Sigma$ & \\
\hline C. $8^{*}$ & 5.00 & 4.36 & 0.83 & 5.00 & 4.36 & 1.13 & 5.00 & 4.36 & 0.98 & $1^{\circ}$ \\
\hline C. 13 * & 4.00 & 3.89 & 0.92 & 4.00 & 4.04 & 0.79 & 4.00 & 3.97 & 0.86 & $2^{\circ}$ \\
\hline C. 14 * & 4.00 & 4.00 & 1.15 & 4.00 & 3.75 & 1.21 & 4.00 & 3.88 & 1.18 & $3^{\circ}$ \\
\hline C. $12 *$ & 4.00 & 3.82 & 1.09 & 4.00 & 3.68 & 1.06 & 4.00 & 3.75 & 1.08 & $4^{\circ}$ \\
\hline C. $17 *$ & 4.00 & 3.71 & 1.21 & 4.00 & 3.64 & 1.28 & 4.00 & 3.68 & 1.25 & $5^{\circ}$ \\
\hline C. $7^{*}$ & 4.00 & 3.71 & 1.05 & 3.00 & 3.50 & 1.14 & 3.50 & 3.61 & 1.10 & $6^{\circ}$ \\
\hline C. $10^{*}$ & 4.00 & 3.82 & 1.09 & 3.00 & 3.39 & 1.13 & 3.50 & 3.61 & 1.11 & $7^{\circ}$ \\
\hline C. $15^{*}$ & 4.00 & 3.61 & 1.17 & 3.50 & 3.36 & 1.13 & 3.75 & 3.49 & 1.15 & $8^{\circ}$ \\
\hline C. 21 * & 4.00 & 3.71 & 1.12 & 3.50 & 3.25 & 1.29 & 3.75 & 3.48 & 1.21 & $9^{\circ}$ \\
\hline C. $22 *$ & 4.00 & 3.50 & 1.20 & 3.00 & 3.32 & 1.22 & 3.50 & 3.41 & 1.21 & $10^{\circ}$ \\
\hline C. $16^{*}$ & 4.00 & 3.61 & 1.17 & 3.00 & 3.18 & 1.31 & 3.50 & 3.40 & 1.24 & $11^{\circ}$ \\
\hline C. $20^{*}$ & 3.00 & 3.36 & 1.22 & 3.00 & 3.04 & 1.29 & 3.00 & 3.20 & 1.26 & $12^{\circ}$ \\
\hline C. $19 *$ & 3.00 & 3.25 & 1.21 & 3.00 & 3.00 & 1.39 & 3.00 & 3.13 & 1.30 & $13^{\circ}$ \\
\hline C..${ }^{*}$ & 3.00 & 3.14 & 1.27 & 3.00 & 2.93 & 1.30 & 3.00 & 3.04 & 1.29 & $14^{\circ}$ \\
\hline C. $11 *$ & 3.00 & 3.18 & 1.12 & 3.00 & 2.86 & 1.15 & 3.00 & 3.02 & 1.14 & $15^{\circ}$ \\
\hline C. $18^{*}$ & 2.00 & 2.71 & 1.24 & 2.00 & 2.46 & 1.04 & 2.00 & 2.59 & 1.14 & $16^{\circ}$ \\
\hline
\end{tabular}

*: BP applicable to deconstruction and construction activities. 
The results obtained for the viability of the BP show that the following BP obtained a viability index $\left(\operatorname{Iv}_{\mathrm{X}}\right)$ below 3.00: using machinery for the management of CDW (crushers/compactors), buying bulk materials or using mechanical dosages. The other measures can be considered as medium-high viable $\mathrm{BP}$ for the correct management of $\mathrm{CDW}$.

As for evaluations that indicate the effectiveness of implementing a best practice in the work, the agents surveyed highlighted as more effective measures (Iex greater than 4.00): to hire authorized companies for the management of the CDW and to respect the instructions of the manufacturer regarding the collection and transport of the material. In addition, placing a container for each waste was the second most valued BP. Both results agree with the results obtained in the study by Villoria et al. [16].

Finally, a comparison between the results obtained and the ones obtained by the previous researchers Lu and Yuan [32], Wang et al. [21] and Villoria et al. [16] is shown in Figures 2 and 3. It is observed that in general the results are similar, both for the BP in the execution phase and in the design phase.

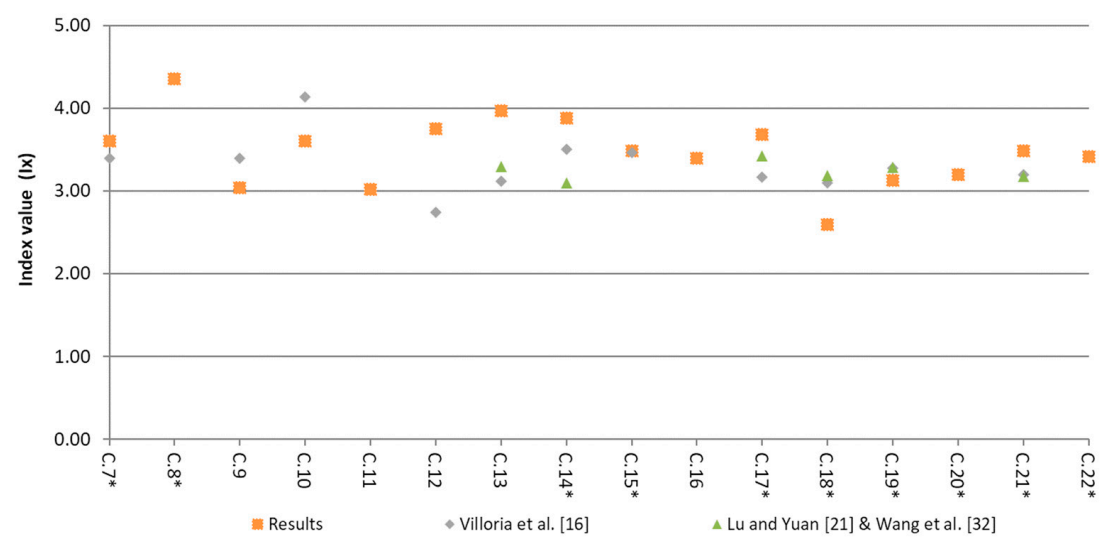

Figure 2. Comparison of the indexes obtained in the execution phase with those obtained by other studies. $[16,21,32]$.

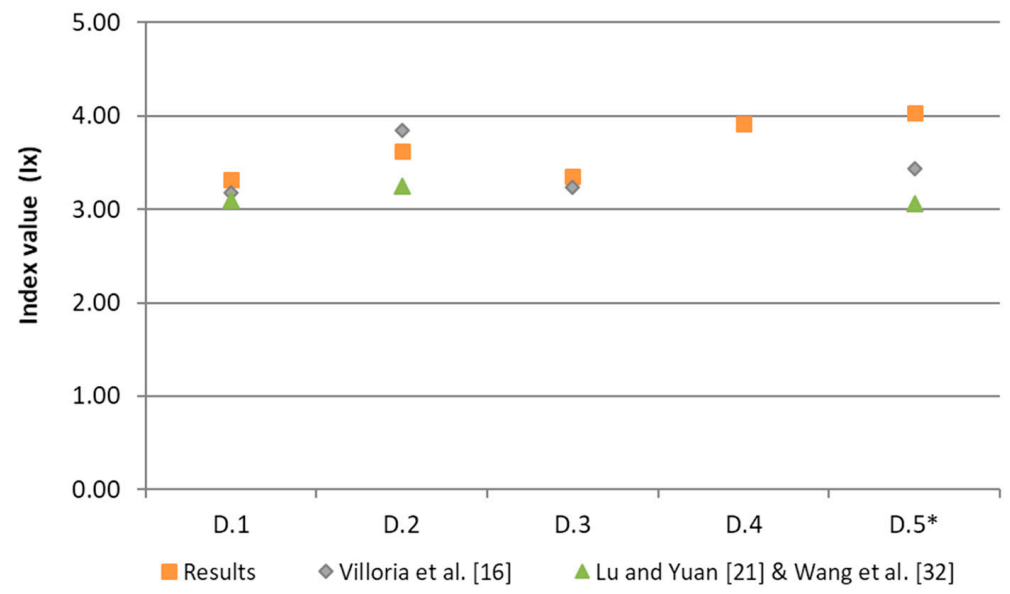

Figure 3. Comparison of the indexes obtained in the design phase with those obtained by other studies. [16,21,32].

All the BP analyzed for rehabilitation works were rated better or the same as in the previous studies except for:

- $\quad$ The purchase of bulk materials to reduce packaging and generate less waste.

- Hiring suppliers who manage the waste of their products and/or having some type of environmental certificate. 
- $\quad$ The use of machinery for the management of CDW (crushers and compactors).

In particular, the use of onsite technologies for CDW recycling was the worst evaluated measure for rehabilitation works and with greater deviation compared to the previous results which focused on new construction works. This fact is mainly due to the usual lack of space in this type of works, making it less viable their use in this type of works compared to the works of new construction.

\section{Conclusions}

The conclusions reached within this study reveal the current use of 27 best practices in the design and execution phases of a building rehabilitation/deconstruction project as well as it values their effectiveness and viability. In particular, Figure 4 highlights the ranking of best practices according to each phase of the building project. However, future research analyzing the influence of implementing best practices on a real case study should be developed, considering the different phases of a building project.

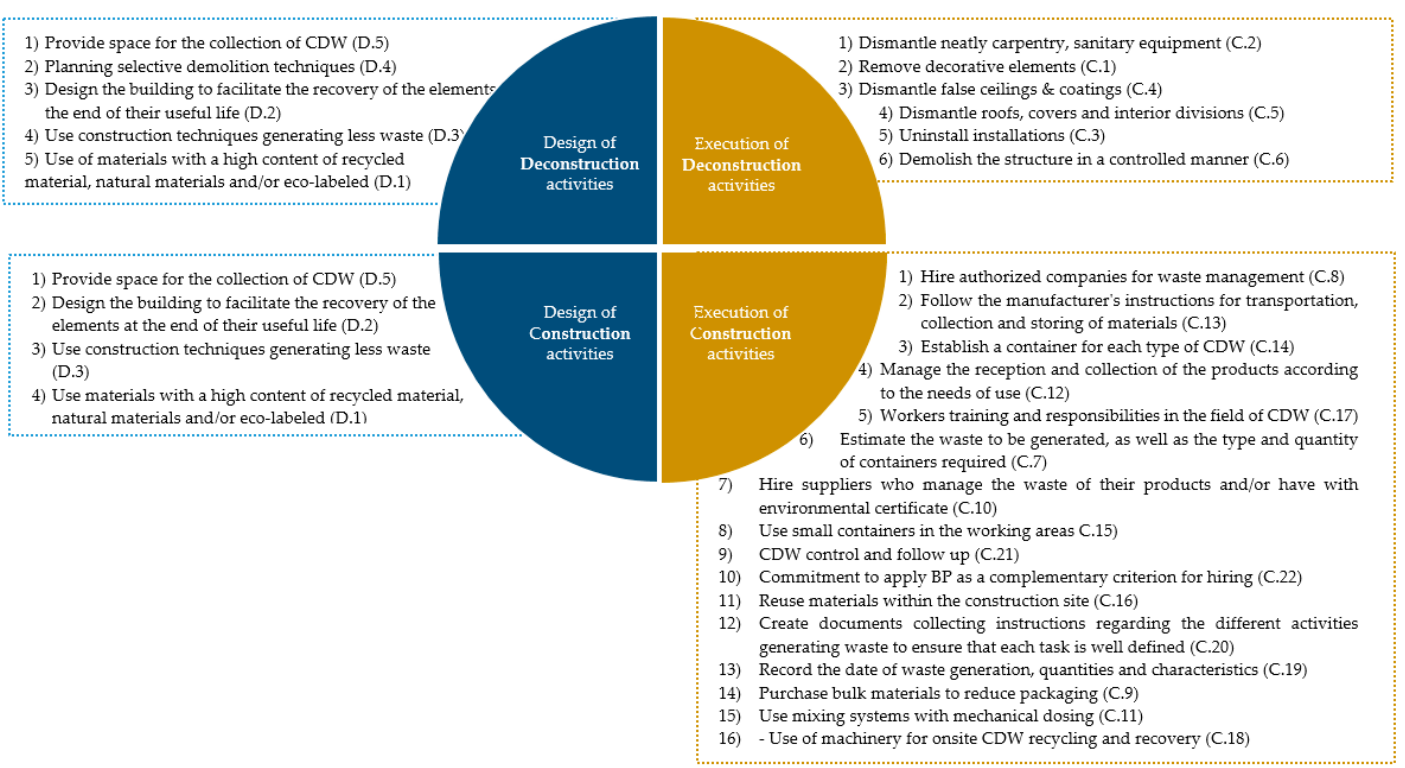

Figure 4. Scheme of best practices for building rehabilitation and deconstruction projects ranked according to their viability and effectiveness.

In particular, the results for best practice in design phase reveal that only $12 \%$ of the respondents usually design the building to facilitate the valorization of the constructive elements at the end of their useful life, despite being a measure valued with an average index of 3.36. In addition, using materials with high content of recycled material ( $\mathrm{Ix}=3.32)$, is only implemented by less than $25 \%$ of the agents surveyed. This may be due to the lack of regulations that establish technical recommendations and prescriptions that contemplate the valorization of $\mathrm{CDW}$ as an alternative raw material in the manufacture of new recycled construction materials.

With regard to best practices in execution phase, it is observed that one of the five best-valued measures "Managing the reception and collection on the work of the products according to the needs of use in each moment to avoid the generation of waste of damaged/expired material", is only implemented regularly by $30 \%$ of the respondents. In addition, the results reveal that only $70 \%$ of respondents routinely implement the most valued measure "Hiring authorized companies for the management of CDW" and $60 \%$ the second "Respecting the manufacturer's directions regarding the transport, collection and commissioning".

Also, best practices such as: recording CDW generation or performing a control/monitoring of CDW management, are implemented by little more than $14 \%$ and $28 \%$ (respectively), so that most of the agents surveyed do not implement best practices that allow them to perform a process of continuous 
improvement. In addition, it is noteworthy that only $14 \%$ record CDW generation, while $57.14 \%$ claim to estimate CDW generation. Therefore, if there are few agents that record the generated waste, the estimates will be, for the most part, made with pre-established generation ratios, which in many cases do not correspond to reality. Finally, using small containers in the work areas is considered a medium measure $(\mathrm{Ix}=3.49)$, which is usually implemented by $25 \%$ of the agents surveyed.

Supplementary Materials: The following are available online at http://www.mdpi.com/2071-1050/11/10/2796/s1.

Author Contributions: Conceptualization, M.D.R.M., P.V.S.; investigation and methodology, M.D.R.M., P.V.S., J.S.C.A.; formal analysis, C.P.-A., P.V.S.; writing-original draft preparation, P.V.S.; writing-review and editing, M.D.R.M., N.G.P.; supervision, M.D.R.M. and P.V.S.; funding acquisition, M.D.R.M., P.V.S. and J.S.C.A.

Funding: This research was supported by the Ministry of Economy and Competitiveness of the Spanish Government (Project reference number BIA2013-43061-R).

Conflicts of Interest: The authors declare no conflict of interest.

\section{References}

1. Menegaki, M.; Damigos, D. A review on current situation and challenges of construction and demolition waste management. Curr. Opin. Green Sustain. Chem. 2018, 13, 8-15. [CrossRef]

2. Lu, W.; Webster, C.; Peng, Y.; Chen, X.; Zhang, X. Estimating and calibrating the amount of building-related construction and demolition waste in urban China. Int. J. Constr. Manag. 2017, 17, 13-24.

3. Huang, B.; Wang, X.; Kua, H.; Geng, Y.; Bleischwitz, R.; Ren, J. Construction and demolition waste management in China through the 3R principle. Resour. Conserv. Recycl. 2018, 129, 36-44. [CrossRef]

4. US Environmental Protection Agency. Advancing Sustainable Materials Management: 2015 Fact Sheet; US Environmental Protection Agency: Washington, DC, USA, 2018.

5. Eurostat. Eurostat Statistics for Waste Flow Generation 2016. European Commission. Available online: http://epp.eurostat.ec.europa.eu/portal/page/portal/eurostat/home/ (accessed on 20 June 2019).

6. Monier, V.; Hestin, M.; Trarieux, M.; Mimid, S.; Domröse, L.; Van Acoleyen, M.; Hjerp, P.; Mudgal, S. Study on the Management of Construction and Demolition Waste in the EU; Final Report for the European Commission; European Commission: Brussels, Belgium, 2011.

7. European Parliament. Directive 2008/98/CE of the European Parliament and of the council of 19 November 2008 on waste and repealing cerain Directives. Off. J. Eur. Union 2008, 034, 3-30.

8. Liang, H.; He, S.; Lei, X.; Bi, Y.; Liu, W.; Ouyang, C. Dynamic process simulation of construction solid waste (CSW) landfill landslide based on SPH considering dilatancy effects. Bull. Eng. Geol. Environ. 2019, 78, 763-777. [CrossRef]

9. Jia, S.; Yan, G.; Shen, A.; Zheng, J. Dynamic simulation analysis of a construction and demolition waste management model under penalty and subsidy mechanisms. J. Clean. Prod. 2017, 147, 531-545. [CrossRef]

10. Gómez Soberón, J.; Saldaña Márquez, H.; Gámez García, D.C.; Gómez Soberón, M.C.; Arredondo Rea, S.P.; Corral Higuera, R. A comparative study of indoor pavements waste generation during construction through simulation tool. Int. J. Sustain. Energy 2016, 5. [CrossRef]

11. Lukiantchuki, J.A.; de Oliveira, J.R.M.d.S.; Pessin, J.; de Almeida, M.D.S.S. Centrifuge modelling of traffic simulation on a construction waste layer. Int. J. Phys. Model. Geotech. 2017, 18, 290-300. [CrossRef]

12. Del Río Merino, M.; del Solar Serrano, P.; Villoria Sáez, P. Los sistemas de gestión de la calidad en la edificación instrumentos para la reducción del impacto medioambiental. In Proceedings of the Actas del I Congreso Internacional de Construcción Sostenible y Soluciones Ecoeficientes, Sevilla, Spain, 20-22 May 2013; pp. 74-84.

13. FCC Construcción. Memoria de Sostenibilidad; FCC Construcción: Madrid, Spain, 2015.

14. Ramos Arias, M. Proyecto de reciclaje de placas de yeso laminado en ARPADA. In Proceedings of the Workshop of Environmental Impact of Buildings, Madrid, Spain, 24-28 September 2018.

15. Acciona. Acciona Sustainability Report 2016; ACCIONA: Madrid, España, 2016.

16. Villoria Saez, P.; del Río Merino, M.; San-Antonio González, A.; Porras-Amores, C. Best practice measures assessment for construction and demolition waste management in building constructions. Resour. Conserv. Recycl. 2013, 75, 52-62. [CrossRef] 
17. Yuan, H. Barriers and countermeasures for managing construction and demolition waste: A case of Shenzhen in China. J. Clean. Prod. 2017, 157, 84-93. [CrossRef]

18. Ajayi, S.O.; Oyedele, L.O.; Akinade, O.O.; Bilal, M.; Alaka, H.A.; Owolabi, H.A. Optimising material procurement for construction waste minimization: An exploration of success factors. Sustain. Mater. Technol. 2017, 11, 38-46. [CrossRef]

19. Osmani, M.; Villoria Sáez, P. Current and emerging construction waste management status, trends and approaches. In Waste, 2nd ed.; Elsevier: Amsterdam, The Netherlands, 2019.

20. Yuan, H. Critical Management Measures Contributing to Construction Waste Management: Evidence From Construction Projects in China. Proj. Manag. J. 2013, 44, 101-112. [CrossRef]

21. Wang, J.; Yuan, H.; Kang, X.; Lu, W. Critical success factors for on-site sorting of construction waste: A China study. Resour. Conserv. Recycl. 2010, 54, 931-936. [CrossRef]

22. Gangolells, M.; Casals, M.; Forcada, N.; Macarulla, M. Analysis of the implementation of effective waste management practices in construction projects and sites. Resour. Conserv. Recycl. 2014, 93, 99-111. [CrossRef]

23. Li, Z.; Shen, G.Q.; Alshawi, M. Measuring the impact of prefabrication on construction waste reduction: An empirical study in China. Resour. Conserv. Recycl. 2014, 91, 27-39. [CrossRef]

24. Tam, V.W.; Tam, C.M.; Zeng, S.X.; Ng, W.C. Towards adoption of prefabrication in construction. Build. Environ. 2007, 42, 3642-3654. [CrossRef]

25. Osmani, M.; Glass, J.; Price, A.D.F. Architects' perspectives on construction waste reduction by design. Waste Manag. 2008, 28, 1147-1158. [CrossRef]

26. Akinade, O.O.; Oyedele, L.O.; Ajayi, S.O.; Bilal, M.; Alaka, H.A.; Owolabi, H.A.; Bello, S.A.; Jaiyeoba, B.E.; Kadiri, K.O. Design for Deconstruction (DfD): Critical success factors for diverting end-of-life waste from landfills. Waste Manag. 2017, 60, 3-13. [CrossRef] [PubMed]

27. Gálvez-Martos, J.-L.; Styles, D.; Schoenberger, H.; Zeschmar-Lahl, B. Construction and demolition waste best management practice in Europe. Resour. Conserv. Recycl. 2018, 136, 166-178. [CrossRef]

28. Ding, T.; Xiao, J.; Tam, V.W. A closed-loop life cycle assessment of recycled aggregate concrete utilization in China. Waste Manag. 2016, 56, 367-375. [CrossRef]

29. Ajayi, S.O.; Oyedele, L.O.; Bilal, M.; Akinade, O.O.; Alaka, H.A.; Owolabi, H.A. Critical management practices influencing on-site waste minimization in construction projects. Waste Manag. 2017, 59, 330-339. [CrossRef] [PubMed]

30. Bilal, M.; Oyedele, L.O.; Qadir, J.; Munir, K.; Ajayi, S.O.; Akinade, O.O.; Owolabi, H.A.; Alaka, H.A.; Pasha, M. Big Data in the construction industry: A review of present status, opportunities, and future trends. Adv. Eng. Inform. 2016, 30, 500-521. [CrossRef]

31. Villoria Sáez, P.; Santa Cruz Astorqui, J.; del Río Merino, M.; Mercader Moyano, M.d.P.; Rodríguez Sánchez, A. Estimation of construction and demolition waste in building energy efficiency retrofitting works of the vertical envelope. J. Clean. Prod. 2018, 172, 2978-2985. [CrossRef]

32. Lu, W.; Yuan, H. Exploring critical success factors for waste management in construction projects of China. Resour. Conserv. Recycl. 2010, 55, 201-208. [CrossRef]

33. Del Río Merino, M.; Izquierdo Gracia, P.; Salto Weis Azevedo, I. Sustainable construction: Construction and demolition waste reconsidered. Waste Manag. Res. 2010, 28, 118-129. [CrossRef]

34. González Pericot, N.; Villoria Sáez, P.; Del Río Merino, M.; Liébana Carrasco, O. Production patterns of packaging waste categories generated at typical Mediterranean residential building worksites. Waste Manag. 2014, 34, 1932-1938. [CrossRef]

35. Tam, V.W.Y. On the effectiveness in implementing a waste-management-plan method in construction. Waste Manag. 2008, 28, 1072-1080. [CrossRef]

36. Euroconstruct. Peak Construction Reached in 2017, Weaker Momentum in Upcoming Years. Press Release of the 86th EUROCONSTRUCT Conference. Available online: http://www.euroconstruct.org/ec/press/pr2018_86 (accessed on 20 April 2019).

(C) 2019 by the authors. Licensee MDPI, Basel, Switzerland. This article is an open access article distributed under the terms and conditions of the Creative Commons Attribution (CC BY) license (http://creativecommons.org/licenses/by/4.0/). 